\title{
6.これからの抗菌薬臨床試験のあり方 PK/PDの活用
}

ブリストル・マイヤーズ株式会社研究開発本部開発研究部臨床薬理室

平 岡 聖 樹

\section{1.はじめに}

抗菌薬は薬物の作用が，宿主である七トを介して， 感染症の原因菌（起炎菌）の除菌として発現する。そ のため, 薬物-ヒト，ヒト-起炎菌，および起炎菌-薬 物のそれぞれの関係が組み合わさって, 最終的な治療 効果に影響する (Fig. 1). 薬物動態 (PK) は生体が 薬物をどのように処理するかであり, 薬力学 (PD) は薬物が起炎菌あるいは生体にどのように作用するか である，起炎菌に対する薬物の作用は，菌の感受性す なわち最小発育阻止濃度 (minimum inhibitory concentration, MIC) や最小殺菌濃度 (minimum bactericidal concentration, $\mathrm{MBC}$ ) で表され，とくに $\mathrm{MIC}$ は薬物の抗菌力, 菌の感受性の指標として一般 的に用いられる。一方，生体における薬物の吸収・分 布・代謝・排泄 (ADME) の総和としてのPK は，本 質的には感染部位である臟器・組織中の薬物濃度を指 標とするほうがより適切であるが，多くの場合，血漿 （血清）中濃度を指標として用いる。これは，血中の 蛋白質と結合していない遊離薬物は標的藏器・組織内 の遊離薬物と平衡関係にあり，血漿中濃度が臟器内濃 度を代替する指標と考えるからである。

感染症領域では, 薬物に対する菌の感受性, 裏返せ ば薬物の抗菌力が MIC という薬物濃度で把握される ため, PK と治療効果の関係すなわち治療効果を最大 にする投与法が以前から検討されてきた。たとえば 1940 年代には, 感染動物モデルを用いて 1 回投与と 分割投与を比較し，ペニシリンの血中濃度を維持する ことの重要性がすでに検討されている1).

Gentamicin (GM), tobramicin (TOB) や amikacin (AMK) などのアミノグリコシド系 $(\mathrm{AGs})^{2)}$ や vancomycin (VCM), teicoplanin (TEIC) など
抗菌薬

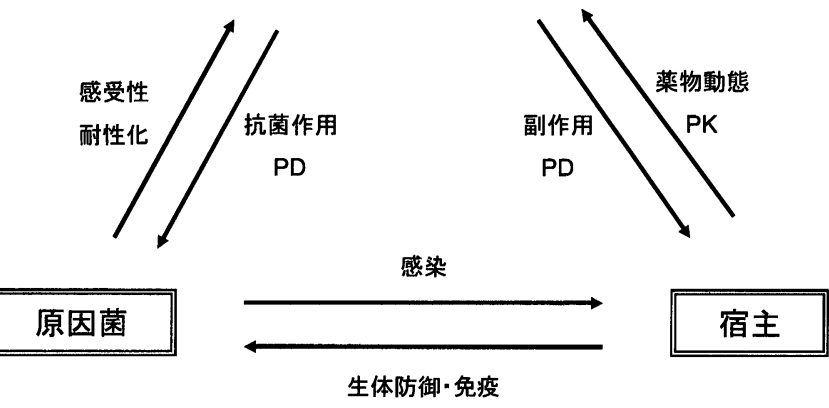

Fig. 1 抗菌薬-宿主-原因菌の関係

のグリコペプチド系 $(\mathrm{GPS})^{3,4)}$ な゙の薬剤については 臨床的に TDM が行われ，血漿中濃度を指標として 用法用量の個別化が行われてきている。これらの TDM の主目的はPDのもう 1 つの側面である安全 性，すなわち副作用を回避・軽減するという点に重点 を置いていたように考えられるが，最近ではより高い 治療効果をめざして TDM が実施されるようになっ てきた ${ }^{4,5)}$.このような TDM の実践の蓄積を背景に, in vitro や動物試験から得られる薬物の抗菌作用の特 徵を反映させ，より高い臨床効果が得られる用法用量 が検討されるようになり，PKと PDを関連させた $\mathrm{PK} / \mathrm{PD}$ 指標が議論されるようになった ${ }^{6,7)}$. 本稿で は，今特集の他稿で論じられている感染動物モデルや in vitro 試験などの非臨床成績や臨床試験から得られ る $\mathrm{PK} / \mathrm{PD}$ 情報が, 臨床開発における治験やその後の 臨床試験にどのように活用され，あるいは活用が考え られているかを概括的にレビューすることによって， 抗菌薬の臨床試験, 臨床開発のあり方を考えてみた い.

なお，感染症領域の $\mathrm{PK} / \mathrm{PD}$ に関連する用語には，

Key words : antimicrobials, PK/PD, clinical study, pharmacokinetics, pharmacodynamics

テ 163-1328 東京都新宿区西新宿 6-5-1 新宿アイランドタワー 
同じ意味で異なる用語が用いられたり, 異なる意味で 類似の用語が用いられたりしており，混乱を避けるた めに用語の標準化が提案されている ${ }^{8,9)}$. 本稿ではこ の提案に沿った用語の定義や略号を用いることとし た.また，抗菌薬の PK とその作用（除菌）の関係 は, ある時点の濃度とその時の反応の関連性ではな く, 薬物投与による曝露と時間経過の総和である臨床

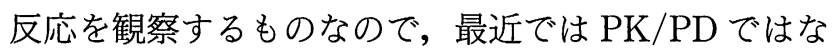
く，より広義に exposure-response $(\mathrm{E}-\mathrm{R})^{10)}$ と呼ば れるようになっているが，本稿では PK/PD を E-R の意味を含む広義に用いている。

\section{2. 抗菌薬の $P K / P D$}

AGs は MIC 以上でより高濃度で殺菌作用が強いと いう濃度依存性 ${ }^{11 \sim 13)}$ の殺菌作用を示し, 一方で, 腎 毒性や聴器毒性にはトラフ濃度が関連するという知見 があり，TDM の経験の蓄積や臨床試験から，1日 1 回投与法（患者の $\mathrm{PK}$ に応じて投与量と投与間隔を 調節するので，必ずしも 1 日 1 回投与ではない) が ピーク濃度（抗菌作用）を高くし，トラフ濃度（副作 用）を低くする投与法として検討されてきてい $3^{14,15)}$. AGs と同様に濃度依存的な殺菌作用を有する キノロン系薬 $(\mathrm{QLS})^{12,16,17)}$ では, 臨床効果と関連する $\mathrm{PK} / \mathrm{PD}$ 指標として, $\mathrm{AUC} / \mathrm{MIC}$ 比が適切と考えられ

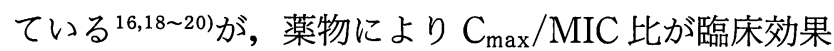
と相関するという報告 ${ }^{21)}$ ある。

一方，ペニシリン系 (PCs)，セファロスポリン系 (CEPs) やカルバペネム系 (CBPs) などの $\beta$-ラクタ 厶系薬（BLs）では MICをある程度以上超える濃度 では，殺菌作用の増強はみられず22)，むしろ MICを 基準として，一定濃度を超えている時間の長さに依存 することが知られている ${ }^{23,24)}$.このような時間依存的 な殺菌作用から，BLs では，血漿中濃度が MIC 以上 である時間を 24 時間に対する割合で表した指標 （ $\mathrm{T}>\mathrm{MIC}$ ）が臨床効果と関連する指標として広く用い られている25 28).

マクロライド系薬（MLs）も殺菌作用の濃度依存 性は顕著ではなく, BLs と同様な時間依存的な作用 を示すため，臨床効果と関連する指標として T > MIC が検討されているが22,27), azithromycin (AZM) ${ }^{22) や ~}$ MLs と類似の作用機作を持つケトライド系 (KLs) の telithromycin (TEL) ${ }^{29)}$ では, AUC/MIC 比が臨 床効果と関連するという報告もある.これらの薬物で は，in vitro の殺菌作用に濃度依存性がみられるとと もに，細胞への薬物の移行性が高く，標的部位の分布
抗菌作用

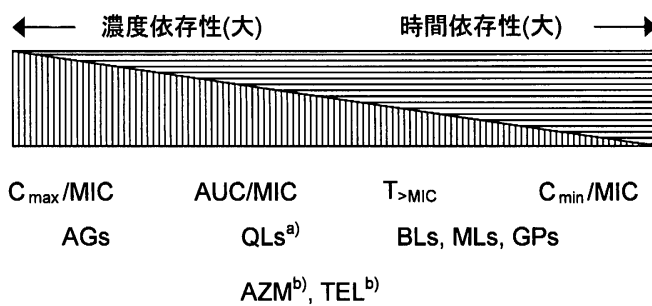

Fig. 2 抗菌作用の濃度依存性/時間依存性と PK/PD 指標の関係の概念図

AGs：アミノグリコシド系, QLs：キノロン系, BLs： $\beta$-ラクタム系, MLs：マクロライド系, GPs：グリコペプチド系, AZM：azithromycin, TEL : telithromycin

${ }^{a)} \mathrm{C}_{\max } / \mathrm{MIC}$ 比が臨床効果と相関するという報告もある ${ }^{21)}$.

b)おもに，生体内で作用が持続することによる22).

濃度が高いため作用が持続するという PK 上の特性 を反映していると考えられる22,30).

また，GPs の VCM や TEIC は濃度依存的という より時間依存的な殺菌作用を示し ${ }^{31)}, \mathrm{BLs}$ と同様に MIC を超える濃度を維持する時間, すなわち $\mathrm{T}>\mathrm{MIC}$ が臨床効果と関連する指標とされ ${ }^{32)}$, 臨床的には，血 漿蛋白結合率を考慮して, 一定以上のトラフ濃度 $\left(\mathrm{C}_{\mathrm{min}}\right)$ を維持することが実践されている ${ }^{5,33)}$.

以上のような抗菌作用の濃度依存性/時間依存性と $\mathrm{PK} / \mathrm{PD}$ 指標との関係を模式的に示すと Fig. 2 のよう に概略できる。

\section{3．抗菌薬の臨床試験における PK/PD の利用}

臨床試験に打ける PK/PD の活用を考えると，1） $\mathrm{PK} / \mathrm{PD}$ 情報を試験デザイン・計画に利用することと， 2 ）薬物の特性把握のために $\mathrm{PK} / \mathrm{PD}$ 情報を得ること の 2 つの側面がある. 抗菌薬では薬物の作用（菌の増 殖阻害・殺菌）と濃度の関連性が直接的であり, in vitro および感染動物モデルを用いた非臨床試験から， 臨床に有用な情報が得られる ${ }^{34,35)}$.

一方，抗菌薬の臨床開発においては，用量検討ある いは用量確認試験と呼ばれる比較的少数例の試験で臨 床用量が検討され, 有効性と安全性を標準的治療法と 比較する第III相試験の投与量が選択されている. Table に過去 4 年間（2001〜2004 年）に国内で承認 された 5 種の抗菌薬について, 用量検討・確認試験の

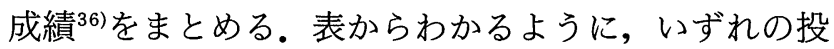
与群も有効率は高く，2３用量群間に概して差はみ られない．抗菌薬領域では，有効率が高い標準療法の ある感染症を対象とし，十分な臨床効果が期待できる 
Table 2001 年以降に国内で承認された抗菌薬の用量検討・確認試験a)

\begin{tabular}{|c|c|c|c|c|}
\hline 薬剤 & 対象感染症 & 用量 & 有効率（例数） & 菌消失率（菌株数） \\
\hline \multirow[t]{2}{*}{ TEL } & 肺炎（軽症，中等症） & 低用量 & $92.9 \%(39 / 42)$ & $92.9 \%(13 / 14)$ \\
\hline & & 高用量 & $95.8 \%(46 / 48)$ & $95.7 \%(22 / 23)$ \\
\hline \multirow[t]{3}{*}{ PUFX } & 慢性気道感染症 & 低用量 & $84.6 \%(22 / 26)$ & $81.8 \%(9 / 11)$ \\
\hline & & 高用量 & $89.3 \%(25 / 28)$ & $90.9 \%(10 / 11)$ \\
\hline & & OFLX & $96.4 \%(27 / 28)$ & $100 \%(13 / 13)$ \\
\hline \multirow[t]{3}{*}{ PUFX } & 複雑性尿路感染症 & 低用量 & $75.0 \%(24 / 32)$ & $81.6 \%(31 / 38)$ \\
\hline & & 高用量 & $73.3 \%(22 / 30)$ & $83.7 \%(36 / 43)$ \\
\hline & & OFLX & $90.3 \%(28 / 31)$ & $92.1 \% \quad(35 / 38)$ \\
\hline \multirow[t]{3}{*}{ GFLX } & 慢性気道感染症 & 低用量 & $97.1 \% \quad(33 / 34)$ & $76.9 \% \quad(20 / 26)$ \\
\hline & & 中用量 & $86.7 \% \quad(26 / 30)$ & $77.8 \%(14 / 18)$ \\
\hline & & 高用量 & $94.3 \%(33 / 35)$ & $80.0 \%(16 / 20)$ \\
\hline \multirow[t]{3}{*}{ GFLX } & 複雑性尿路感染症 & 低用量 & $85.7 \%(30 / 35)$ & $90.2 \%(46 / 51)$ \\
\hline & & 中用量 & $81.6 \%(31 / 38)$ & $90.0 \%(54 / 60)$ \\
\hline & & 高用量 & $94.6 \%(35 / 37)$ & $96.4 \% \quad(53 / 55)$ \\
\hline \multirow[t]{3}{*}{ PZFX } & 複雑性尿路感染症 & 低用量 & $86.7 \%(26 / 30)$ & $92.6 \%(50 / 54)$ \\
\hline & & 高用量 & $78.8 \%(26 / 33)$ & $91.8 \%(45 / 49)$ \\
\hline & & $\mathrm{CAZ}$ & $88.9 \% \quad(24 / 27)$ & $97.6 \%(41 / 42)$ \\
\hline \multirow[t]{3}{*}{ PZFX } & 細菌性肺炎 & 低用量 & $100 \%(32 / 32)$ & $92.9 \%(13 / 14)$ \\
\hline & & 高用量 & $92.6 \%(25 / 27)$ & $100 \%(8 / 8)$ \\
\hline & & $\mathrm{CAZ}$ & $93.1 \%(27 / 29)$ & $100 \%(11 / 11)$ \\
\hline \multirow[t]{3}{*}{ BIPM } & 慢性気管支炎 & 低用量 & $100 \%(10 / 10)$ & $100 \%(6 / 6)$ \\
\hline & & 高用量 & $90.0 \% \quad(9 / 10)$ & $100 \%(3 / 3)$ \\
\hline & & $\mathrm{IPM} / \mathrm{CS}$ & $91.7 \%(11 / 12)$ & $100 \%(9 / 9)$ \\
\hline \multirow[t]{3}{*}{ BIPM } & 複雑性尿路感染症 & 低用量 & $80.0 \% \quad(8 / 10)$ & $85.7 \%(12 / 14)$ \\
\hline & & 高用量 & $100 \%(11 / 11)$ & $100 \%(21 / 21)$ \\
\hline & & $\mathrm{IPM} / \mathrm{CS}$ & $100 \%(14 / 14)$ & $94.1 \%(16 / 17)$ \\
\hline
\end{tabular}

TEL : telithromycin, PUFX : prulifloxacin, GFLX : gatifloxacin, OFLX : ofloxacin, PZFX : pazufloxacin, CAZ : ceftazidime, BIPM : biapenem, IPM/CS : imipenem/cilastatin a)これらの試験成績は新薬審査報告公開資料 ${ }^{36)}$ から引用した。

用量を低用量群としており，その用量は，1）in vitro および in vivo の非臨床試験成績，2）PK と忍 容性を中心とする第 I 相試験成績および 3 ）初期第 II 相試験成績に基づいて選択されている.さらに, 用量 検討・確認試験では, 期待される高い有効率に基づく 用量間比較の例数設計は行われないことや患者の病態 および起炎菌種・感受性の関係が多様で症例の背景を 均一とできないことが抗菌薬領域の特徵となってい る.

このような抗菌薬領域の臨床試験の特殊性を考慮

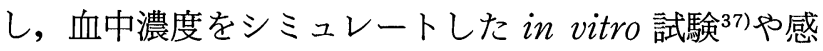
染動物モデル38)などの非臨床試験から得られる $\mathrm{PK} /$ $\mathrm{PD}$ 情報を利用し, 臨床試験用量を設定するなど，よ り合理的な考え方が試みられている ${ }^{399}$. 試験デザイン の検討や臨床用量の推定への応用という点では, 臨床
第 I 相試験におけるモデル化とシミュレーションの利 用 ${ }^{40)}$ P $\mathrm{PK}$ の分布情報と MIC の分布情報をもとに Monte Carlo シミュレーションにより, 種々の投与 方法について $\mathrm{PK} / \mathrm{PD}$ 指標の分布を検討する手法 ${ }^{41)}$ 知られている.このように, 化合物の $\mathrm{PK} / \mathrm{PD}$ 特性に 合致した投与方法を検討し, 合理的に臨床用量を設定 し，臨床試験計画に反映させることで，臨床試験の成 功確率はより高くなると考えられる。

一方, 臨床試験から $\mathrm{PK} / \mathrm{PD}$ 情報を得るという観点 では, 第II相, III相試験あるいは市販後の臨床試験に おいて, 臨床評価とともに $\mathrm{PK}$ および起炎菌の MIC を評価し, 前述のような $\mathrm{PK} / \mathrm{PD}$ 指標と臨床効果の関 係が検討されている ${ }^{21,42)}$. 第III相比較試験では単一用 量で試験されることが多く, 用量一反応を幅のある範 囲で評価することはできないが，被験者ごとに変動を 
もつ $\mathrm{PK}$ と症例ごとに異なる起炎菌の感受性 (MIC) を用いた $\mathrm{PK} / \mathrm{PD}$ 指標により，曝露 $(\mathrm{PK})$ と臨床反応（PD）の関係を広がりのある範囲で評価 できる ${ }^{21,42)}$.すなわち, 有効性と安全性について, $\mathrm{PK}$ パラメータとの関連性を評価し, 注目すべきパラ メータは何かということが検討できるため, 臨床試験 の結果の解釈にも寄与しうる。こうした臨床試験にお いて患者の $\mathrm{PK}$ 評価が行われるようになった背景に は，同一患者で頻回の採血を必要としない母集団薬物 動態 (PPK) 解析 ${ }^{43 \sim 45)}$ の手法が普及し, $\mathrm{PK} / \mathrm{PD}$ 解析 の医薬品開発への応用 46,47$)$ が議論され, 抗菌薬領域に 限らず，広く臨床試験に応用できる環境が整ってきた ことに加えて, $\mathrm{PK} / \mathrm{PD}$ 解析の有用性が認識されるよ うになったことが考えられる ${ }^{48)}$.

薬効を評価する臨床試験で $\mathrm{PK} / \mathrm{PD}$ を検討すること により, 有効性や安全性と PK との関連性を検討で き, 選択した臨床用量の妥当性を裏付ける重要な情報 が得られるものと考えられる。さらに，PPK 解析の 情報を含むこれらの $\mathrm{PK} / \mathrm{PD}$ 情報を得ることにより， 市販後の医療の場で, 薬物療法の個別化やより適切な 投与法を検討するための基礎とすることができる.

\section{4.まとめ}

抗菌薬はその抗菌作用の機序や PK の特性に基づ き, $\mathrm{C}_{\max }$ あるいは $\mathrm{C}_{\max } / \mathrm{MIC}$ 比, $\mathrm{AUC} / \mathrm{MIC}$ 比, $\mathrm{T}>\mathrm{MIC}$, $\mathrm{C}_{\min }$ あるいは $\mathrm{C}_{\min } / \mathrm{MIC}$ 比などの $\mathrm{PK} / \mathrm{PD}$ 指標を用 い, in vitro あるいは動物モデルを用いた $\mathrm{PK} / \mathrm{PD}$ 評 価, 初期薬物動態試験成績と起炎菌の感受性分布と分 離頻度を用いた Monte Carlo シミュレーション，患 者集団における PPK 解析, Phase II/III試験におけ る $\mathrm{PK} / \mathrm{PD}$ 解析など, 抗菌薬の臨床試験の種々の場面 で PK/PD に関する検討が行われ，その情報が臨床開 発に利用されることを概説した。

抗菌薬の開発は最近とくに困難になってきていると いわれるが，薬物の特徵を適切に反映した開発計画の 下に, PK/PD の特性を生かした臨床試験をデザイン することが重要と考えられ，従来の抗菌薬の開発手法 にとらわれることなく, PK/PD を考慮した開発方針 と臨床試験計画が有用なものと考える。

先には触れなかったが, $\mathrm{PK} / \mathrm{PD}$ の検討は耐性菌対 策としても有用な手法であり，耐性菌の出現を最小限 とするため，まだ確立された概念とはいえないが， mutant prevention concentration (MPC) p mutant selection window（MSW）を考慮した用法 用量の検討も議論されている49 51). 耐性菌を選択し
にくい用法用量を検討することは，市販後において， 抗菌薬の医療上の有用性を維持するためにも重要な視 点である。

最後に，近年，欧米やわが国の多くの製薬企業の新 薬開発の目標は細菌感染症から離れ, 新規抗菌薬の開 発を中断したり縮小したりしている52). 抗菌薬の適切 な使用を推進することにより，耐性菌の出現と蔓延を 最小限にとどめる努力は続けられているものの, 抗菌 薬の宿命として, 臨床使用に伴う菌の耐性化は避けら れないため, 新規抗菌薬の開発努力は止むことなく続 ける必要がある ${ }^{52,53)}$. 薬物の抗菌作用 (PD) の特性 と薬物動態 $(\mathrm{PK})$ の特性を考慮し, 非臨床試験から 臨床試験へ $\mathrm{PK} / \mathrm{PD}$ の観点を生かして開発することに より，より効果的で効率的な臨床開発が進められるこ とと考えられる.

\section{文献}

1) Eagle H, Fleischman R, Musselman $A D$. Effect of schedule of administration on therapeutic efficacy of penicillin : importance of the aggregate time penicillin remains at effectively bactericidal levels. Am J Med $1950 ; 9$ : 280-99.

2) van Lent-Evers NA, Mathot RA, Geus WP, van Hout BA, Vinks AA. Impact of goal-oriented and model-based clinical pharmacokinetic dosing of aminoglycosides on clinical outcome : a cost-effectiveness analysis. Ther Drug Monit 1999 ; $21: 63-73$.

3) MacGowan AP. Pharmacodynamics, pharmacokinetics, and therapeutic drug monitoring of glycopeptides. Ther Drug Monit $1998 ; 20: 473-7$.

4) Iwamoto T, Kagawa $Y$, Kojima M. Clinical efficacy of therapeutic drug monitoring in patients receiving vancomycin. Biol Pharm Bull 2003 ; 26 : 876-9.

5) Darley ES, MacGowan AP. The use and therapeutic drug monitoring of teicoplanin in the UK. Clin Microbiol Infect $2004 ; \mathbf{1 0}: 62-9$.

6) Hyatt JM, McKinnon PS, Zimmer GS, Schentag JJ. The importance of pharmacokinetic/pharmacodynamic surrogate markers to outcome. Focus on antibacterial agents. Clin Pharmacokinet $1995 ; 28: 143-60$.

7) Burgess DS. Use of pharmacokinetics and pharmacodynamics to optimize antimicrobial treatment of Pseudomonas aeruginosa infections. Clin Infect Dis 2005; 40 (Suppl 2) : S 99-104.

8) Mouton JW, Dudley MN, Cars O, Derendorf H, Drusano GL. Standardization of pharmacokinetic/pharmacodynamic (PK/PD) terminology for anti-infective drugs. Int J Antimicrob Agents $2002 ; 19: 355-8$.

9) Mouton JW, Dudley MN, Cars O, Derendorf H, Drusano GL. Standardization of pharmacokinetic/pharmacodynamic (PK/PD) terminology for anti-infective drugs : an update. $J$ Antimicrob Chemother $2005 ; 55: 601-7$.

10) U.S. Food and Drug Administration (FDA). Guidance for Industry: Exposure-Response Relationships-Study Design, Data Analysis, and Regulatory Applications. FDA 2003. Available at http://www.fda.gov/cder/guidance/5341fnl.pdf 
(successfully accessed on Apr. 10, 2005)

11) Gerber AU, Feller-Segessenmann C. In-vivo assessment of in-vitro killing patterns of Pseudomonas aeruginosa. $J$ Antimicrob Chemother 1985 ; 15 (Suppl A) : 201-6.

12) Mouton JW, Vinks AA. Pharmacokinetic/pharmacodynamic modeling of antibacterials in vitro and in vivo using bacterial growth and kill kinetics: the minimum inhibitory concentration versus stationary concentration. Clin Pharmacokinet $2005 ; \mathbf{4 4}: 201-10$.

13) Begg EJ, Peddie BA, Chambers ST, Boswell DR. Comparison of gentamicin dosing regimens using an in-vitro model. $J$ Antimicrob Chemother 1992; 29:427-33.

14) Freeman $C D$, Nicolau DP, Belliveau PP, Nightingale $C H$. Once-daily dosing of aminoglycosides : review and recommendations for clinical practice. $J$ Antimicrob Chemother $1997 ; 39: 677-86$.

15) Nicolau DP, Wu AH, Finocchiaro S, Udeh E, Chow MS, Quintiliani $\mathrm{R}$, Nightingale $\mathrm{CH}$. Once-daily aminoglycoside dosing: impact on requests and costs for therapeutic drug monitoring. Ther Drug Monit $1996 ; 18: 263-6$.

16) Turnidge J. Pharmacokinetics and pharmacodynamics of fluoroquinolones. Drugs $1999 ; 58$ (Suppl 2) : 29-36.

17) Firsov AA, Vostrov SN, Lubenko IY, Zinner SH, Portnoy YA. Concentration-dependent changes in the susceptibility and killing of Staphylococcus aureus in an in vitro dynamic model that simulates normal and impaired gatifloxacin elimination. Int $J$ Antimicrob Agents $2004 ; 23: 60-6$.

18) Forrest A, Nix DE, Ballow CH, Goss TF, Birmingham MC, Schentag JJ. Pharmacodynamics of intravenous ciprofloxacin in seriously ill patients. Antimicrob Agents Chemother $1993 ; 37: 1073-81$.

19) Lister PD. Pharmacodynamics of gatifloxacin against Streptococcus pneumoniae in an in vitro pharmacokinetic model: impact of area under the curve/MIC ratios on eradication. Antimicrob Agents Chemother $2002 ; 46: 69-74$.

20) Ernst EJ, Klepser ME, Petzold CR, Doern GV. Evaluation of survival and pharmacodynamic relationships for five fluoroquinolones in a neutropenic murine model of pneumococcal lung infection. Pharmacotherapy $2002 ; 22: 463-70$.

21) Preston SL, Drusano GL, Berman AL, Fowler CL, Chow AT, Dornseif B, Reichl V, Natarajan J, Corrado M. Pharmacodynamics of levofloxacin: a new paradigm for early clinical trials. JAMA $1998 ; 279: 125-9$.

22) Van Bambeke F, Tulkens PM. Macrolides: pharmacokinetics and harmacodynamics. Int $J$ Antimicrob Agents $2001 ;$ 18(Suppl 1) : S 17-23.

23) Craig W. Pharmacodynamics of antimicrobial agents as a basis for determining dosage regimens. Eur J Clin Microbiol Infect Dis 1993 ; 12 (Suppl 1) : S 6-8.

24) Turnidge JD. The pharmacodynamics of beta-lactams. Clin Infect Dis 1998; $27: 10-22$.

25) Craig WA, Andes D. Pharmacokinetics and pharmacodynamics of antibiotics in otitis media. Pediatr Infect Dis $J 1996 ; 15: 255-9$.

26) MacGowan AP, Bowker KE. Sequential antimicrobial therapy: pharmacokinetic and pharmacodynamic considerations in sequential therapy. $J$ Infect $1998 ; 37$ (Suppl 1) : 30-6.

27) Nicolau DP. Predicting antibacterial response from pharmacodynamic and pharmacokinetic profiles. Infection 2001 ; 29(Suppl 2) : 11-5.

28) Frimodt-M $\phi 1$ ler N. How predictive is $\mathrm{PK} / \mathrm{PD}$ for antibacterial agents? Int $J$ Antimicrob Agents $2002 ; 19: 333-9$.
29) Drusano G. Pharmacodynamic and pharmacokinetic considerations in antimicrobial selection: focus on telithromycin. Clin Microbiol Infect 2001; 7(Suppl 3) : 24-9.

30) Muller-Serieys C, Andrews J, Vacheron F, Cantalloube C. Tissue kinetics of telithromycin, the first ketolide antibacterial. J Antimicrob Chemother $2004 ; 53: 149-57$.

31) Bailey EM, Rybak MJ, Kaatz GW. Comparative effect of protein binding on the killing activities of teicoplanin and vancomycin. Antimicrob Agents Chemother $1991 ; 35$ : 108992.

32) Lowdin E, Odenholt I, Cars O. In vitro studies of pharmacodynamic properties of vancomycin against Staphylococcus aureus and Staphylococcus epidermidis. Antimicrob Agents Chemother 1998; 42:2739-44.

33) Pea F, Bertolissi M, Di Silvestre A, Poz D, Giordano F, Furlanut M. TDM coupled with Bayesian forecasting should be considered an invaluable tool for optimizing vancomycin daily exposure in unstable critically ill patients. Int $J$ Antimicrob Agents $2002 ; 20: 326-32$.

34) Corvaisier S, Maire PH, Bouvier d'Yvoire MY, Barbaut X, Bleyzac N, Jelliffe RW. Comparisons between antimicrobial pharmacodynamic indices and bacterial killing as described by using the Zhi model. Antimicrob Agents Chemother 1998; 42:1731-7.

35) Lubenko IY, Vostrov SN, Portnoy YA, Zinner SH, Firsov AA. Bacterial strain-independent AUC/MIC and strainspecific dose-response relationships reflecting comparative fluoroquinolone anti-pseudomonal pharmacodynamics in an in vitro dynamic model. Int $J$ Antimicrob Agents $2002 ; 20$ : 44-9.

36）独立行政法人医薬品医療機器総合機構医薬品医療機器情報提供 ホームページ, 新薬の承認に関する情報. http://www.info. pmda.go.jp/shinyaku/shinyaku_index.html おょび財団法人 日本薬剤師研修センター, 新薬の承認に関する情報のページ. http://www.jpec.or.jp/contents/c01/link.html（2005 年 4 月 10 日現在, アクセスを確認).

37) Zhanel GG, Walters $M$, Laing $N$, Hoban DJ. In vitro pharmacodynamic modelling simulating free serum concentrations of fluoroquinolones against multidrug-resistant Streptococcus pneumoniae. J Antimicrob Chemother 2001 ; 47:43540.

38) Andes D, Craig WA. Animal model pharmacokinetics and pharmacodynamics: a critical review. Int $J$ Antimicrob Agents $2002 ; 19: 261-8$.

39) Drusano GL, Preston SL, Hardalo C, Hare R, Banfield C, Andes D, Vesga O, Craig WA. Use of preclinical data for selection of a phase II/III dose for evernimicin and identification of a preclinical MIC breakpoint. Antimicrob Agents Chemother $2001 ; 45: 13-22$.

40) Aarons L, Karlsson MO, Mentre F, Rombout F, Steimer JL, van Peer A; COST B15 Experts. Role of modelling and simulation in Phase I drug development. Eur J Pharm Sci $2001 ; 13: 115-22$.

41) Ambrose PG, Grasela DM. The use of Monte Carlo simulation to examine pharmacodynamic variance of drugs : fluoroquinolone pharmacodynamics against Streptococcus pneumoniae. Diagn Microbiol Infect Dis $2000 ; 38: 151-7$.

42) Ambrose PG, Grasela DM, Grasela TH, Passarell J, Mayer $\mathrm{HB}$, Pierce PF. Pharmacodynamics of fluoroquinolones against Streptococcus pneumoniae in patients with community-acquired respiratory tract infections. Antimicrob Agents Chemother $2001 ; 45: 2793-7$. 
43) Kashuba AD, Ballow CH, Forrest A. Development and evaluation of a Bayesian pharmacokinetic estimator and optimal, sparse sampling strategies for ceftazidime. Antimicrob Agents Chemother $1996 ; 40: 1860-5$.

44) Sun H, Fadiran EO, Jones CD, et al. Population pharmacokinetics. A regulatory perspective. Clin Pharmacokinet 1999 ; 37:41-58.

45) Drusano GL, Preston SL, Van Guilder M, North D, Gombert M, Oefelein M, Boccumini L, Weisinger B, Corrado M, Kahn J. A population pharmacokinetic analysis of the penetration of the prostate by levofloxacin. Antimicrob Agents Chemothor $2000 ; 44: 2046-51$.

46) U.S. Food and Drug Administration (FDA). Guidance for Industry: Population Pharmacokinetics. FDA 1999. Available at http://www.fda.gov/cder/guidance/1852 fnl.pdf (successfully accessed on Apr. 10, 2005)

47) Sheiner LB, Steimer JL. Pharmacokinetic/pharmacodynamic modeling in drug development. Annu Rev Pharmacol Toxicol $2000 ; \mathbf{4 0}: 67-95$
48）今井康彦, 平岡聖樹, 安田早苗ほか. 薬物動態-反応関係を活用 した確実かつ効率的な用量選択に関する一考察. 臨床薬理 $2005 ; 36$ (5) (印刷中).

49) Negri MC, Baquero F. In vitro selective concentrations of cefepime and ceftazidime for AmpC $\beta$-lactamase hyperproducer Enterobacter cloacae variants. Clin Microbiol Infect $1999 ; \mathbf{5}: \mathrm{S} 25-8$.

50) Zhao X, Drlica K. Restricting the selection of antibioticresistant mutants: a general strategy derived from fluoroquinolone studies. Clin Infect Dis 2001 ; 33 (Suppl 3) : S 14756.

51) Blondeau JM, Hansen G, Metzler K, Hedlin P. The role of $\mathrm{PK} / \mathrm{PD}$ parameters to avoid selection and increase of resistance : mutant prevention concentration. J Chemother 2004 ; 16(Suppl 3) : 1-19.

52) Bush K. Related Antibacterial drug discovery in the 21st century. Clin Microbiol Infect 2004; 10 (Suppl 4) : 10-7.

53) Livermore DM. The need for new antibiotics. Clin Microbiol Infect $2004 ; \mathbf{1 0}$ (Suppl 4) : 1-9. 